\title{
The rock art of Madjedbebe (Malakunanja II)
}

\author{
Sally K. May, Paul S.C. Taçon, Duncan Wright, Melissa Marshall, \\ Joakim Goldhahn and Inés Domingo Sanz
}

\section{Introduction}

The western Arnhem Land site of Madjedbebe - a site hitherto erroneously named Malakunanja II in scientific and popular literature but identified as Madjedbebe by senior Mirarr Traditional Owners - is widely recognised as one of Australia's oldest dated human occupation sites (Roberts et al. 1990a:153, 1998; Allen and O'Connell 2014; Clarkson et al. 2017). Yet little is known of its extensive body of rock art. The comparative lack of interest in rock art by many archaeologists in Australia during the 1960s into the early 1990s meant that rock art was often overlooked or used simply to illustrate the 'real' archaeology of, for example, stone artefact studies. As Hays-Gilpen (2004:1) suggests, rock art was viewed as intractable to scientific research, especially under the science-focused "new archaeology" and "processual archaeology" paradigms of the 1960s through the early 1980s'. Today, things have changed somewhat, and it is no longer essential to justify why rock art has relevance to wider archaeological studies.

That said, archaeologists continued to struggle to connect the archaeological record above and below ground at sites such as Madjedbebe. For instance, at this site, Roberts et al. (1990a:153) recovered more than 1500 artefacts from the lowest occupation levels, including 'silcrete flakes, pieces of dolerite and ground haematite, red and yellow ochres, a grindstone and a large number of amorphous artefacts made of quartzite and white quartz'. The presence of ground haematite and ochres in the lowest deposits certainly confirms the use of pigment by the early, Pleistocene inhabitants of this site. However, we know very little about what the materials were used for. Many of the earliest occupation sites in Australia, including Madjedbebe, have revealed finds of ochre with ground facets, sometimes in considerable quantities (Clarkson et al. 2017; Davidson and Noble 1992:139), and it would not be too far-fetched to suggest that the haematite and other ochres were used for cultural 'business', such as body art, decoration of objects (spears, dilly bags, etc.), the production of rock art or other such activities. Whatever the case, here we argue that the rock art is an important part of the archaeological story of Madjedbebe, and it deserves particular attention.

In this chapter, we focus on the 1068 paintings, stencils and beeswax figures that exist above current ground level at Madjedbebe. Our work draws on environmental, archaeological and ethnographic evidence to place the art and the site in their wider regional contexts. 


\section{The study area}

Madjedbebe is in Mirarr Country and currently sits within the Jabiluka Leasehold (Figures 5.1-5.3). It is bordered on all sides by the World Heritage-listed Kakadu National Park. The recording of the site took place as part of the Mirarr Gunwarddebim (Mirarr Rock Art) project, which aims to document, study and promote rock art sites in Mirarr Country.

Keen (1980:147) broadly defines the area of Mirarr Country as covering 'the upper reaches of the Magela Creek, between Leichhardt billabong in the north and Mount Brockman and Whistleduck dreaming in the south, "Urralugoorwa" waterhole in the west and the escarpment in the east'. When we refer to 'Mirarr Country' in this chapter, we are referring both to Country (as Aboriginal concept of ancestrally connected and territorial place) owned by Mirarr directly and the Country they are currently responsible for looking after as part of customary law.

Madjedbebe is a northwest-oriented bluff face that is part of the Djawumbu massif, often referred to as the Djawumbu-Madjawarrnja Complex. The majority of art stretches along a $48.5 \mathrm{~m}$ long panel (Figures 5.1 and 5.2). There is little shelter from the elements at the site. Importantly, earlier living ground surfaces and, most likely, early painted or engraved rock surfaces additional to those that are presently visible, were at considerably lower levels than today. The rock art produced during the earliest occupation of this shelter is likely buried beneath many metres of accumulated sediment.

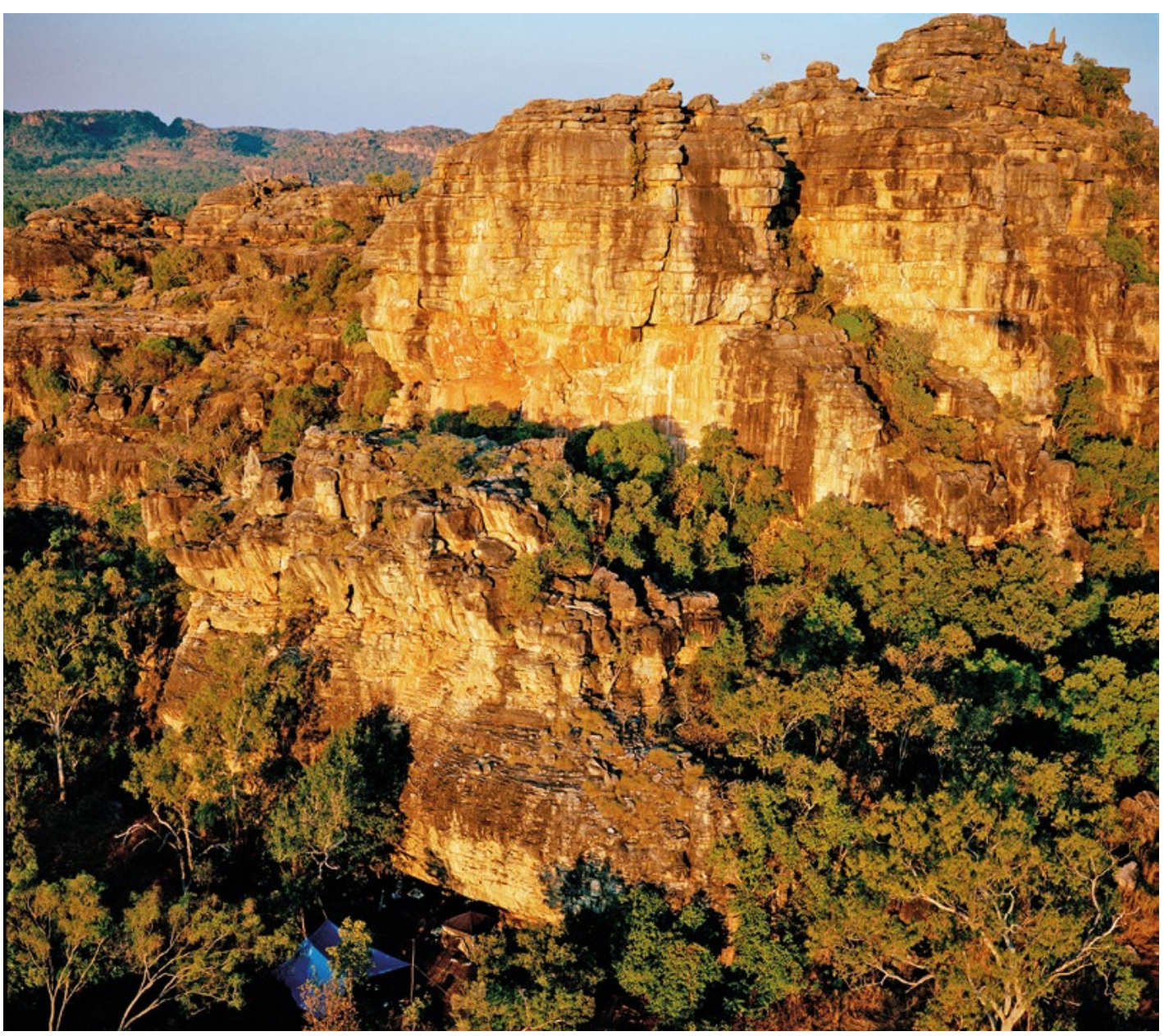

Figure 5.1 Madjedbebe, aerial view, 2012. The rock art can be found at the very base of the rock face. Source: Photograph by Matthew Abbott. 


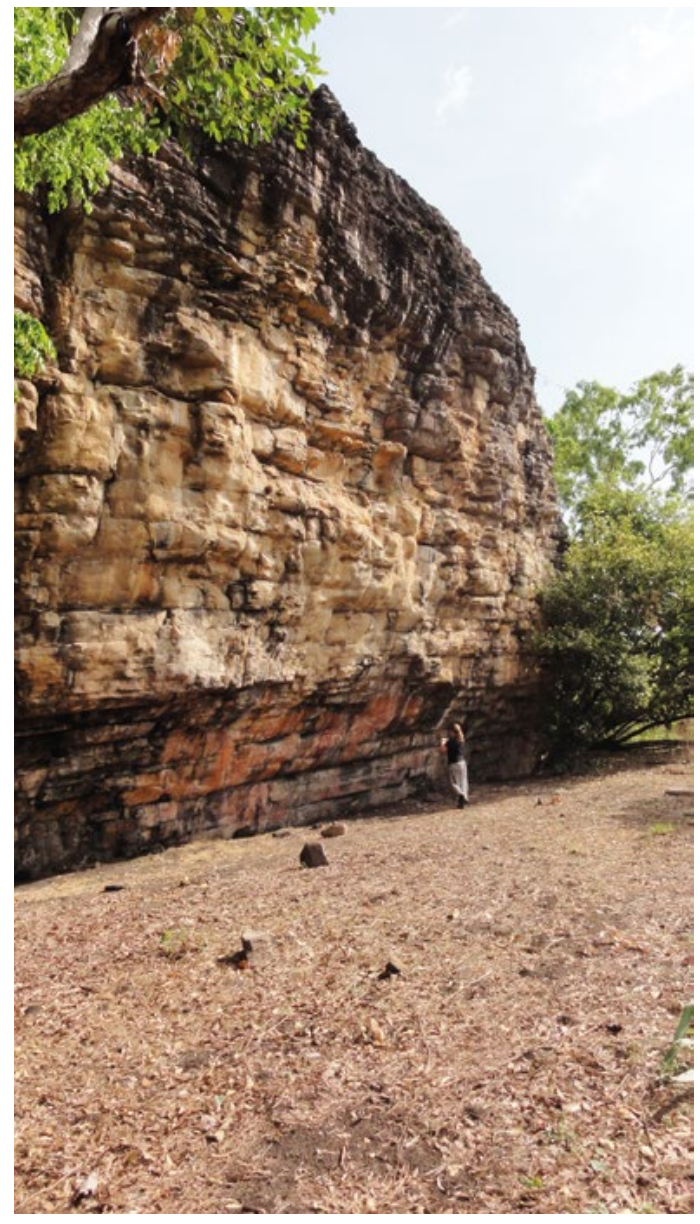

Figure 5.2 View of Madjedbebe showing the height of the rock face and some key painted panels at its lower levels, 2012.

Source: Photograph by Justin $0^{\prime} B$ Brien.

\section{Environmental setting}

At the time that Aboriginal people first moved into the area the sea was some 100 metres below its present level. Jabiluka instead of being 20 metres above sea level and $50 \mathrm{~km}$ inland had an altitude of 120 metres and was over $200 \mathrm{~km}$ inland. Instead of the broad flat Magela floodplain there was a deeply eroded trench sloping up towards the escarpment (Allen 1978:6).

Human-environment relations have long been a subject of interest for researchers working in Arnhem Land (e.g. Allen 1978, 1996; Allen and Barton 1989; Bourke et al. 2007; Brockwell et al. 2009; Faulkner 2009; Jones 1969; Taçon and Brockwell 1995).
Chappell and Shackleton (1986:137; see also Woodroffe et al. 1989) suggest that seas rose from $-130 \mathrm{~m}$ to $-12 \mathrm{~m}$ between 19,000 and 8000 BP, flooding the Sahul land bridge and encroaching on present-day Arnhem Land. During this period, the area was drier than at present, with vegetation and faunal taxa being similar to those of the present-day drier areas south of Kakadu (Brockwell et al. 1995:17). Between 8000 and 6000 BP, seas are thought to have reached $0-3 \mathrm{~m}$ above current levels in northern Australia, a result of glacio-hydroisostaticity (Chappell and Grindrod 1983:67; Lambeck and Chappell 2001). Low-lying areas such as the Magela system and South and East Alligator Rivers plains flooded, and Rhizophora mangroves colonised newly formed estuaries and saline swamps (Woodroffe et al. 1989:749-53). As sea levels dropped and stabilised in the subsequent 'transitional period' (between 5000 and $2500 \mathrm{BP}$ ), coastal plains prograded seaward and mangroves retreated. Major climatic uncertainty, associated with late Holocene ENSO events, occurred and a mosaic landscape of tidal channels, saline swamps and freshwater streams developed (Clark et al. 1992:89; Woodroffe et al. 1989:753). Sediment archives and pollen cores suggest that increased climatic variability, associated with the Little Climatic Optimum (1200$700 \mathrm{BP})$ and Little Ice Age (600-100 BP), occurred during the past 2000 years (Clark and Guppy 1988; Clark et al. 1992; Hope et al. 1985; Jones et al. 2001). A general trend towards increased precipitation and seasonality in the late Holocene enabled stabilisation of the current wetland environment, with seasonally inundated grasslands replacing mangrove swamps (Allen 1996; Bourke et al. 2007; Brockwell et al. 2009:61; Lees 1992:8).

A link may exist between changes in human settlement and the development of estuarine and then freshwater floodplain environments. Between 7000 and 5000 BP new sites appear, including shell middens (Ngarradj Warde Djobkeng, Madjedbebe, Nawamoyn and Malangangerr) containing species of shellfish, fish and crab associated with mangroves and mudflats (Allen 1996:198; Schrire 1982:233). 
Brockwell et al. (2009:61) suggested, 'Increased climatic variation after 4000 BP coincided with increasing numbers of shell mounds, earth mounds and shell middens recorded for this time period, along with continued occupation of rock-shelters'. After 2500 BP, during a period of intensive burning on freshwater floodplains including the Magela system (Clark et al. 1992), an occupation shift occurred away from some rockshelters (e.g. Nawamoyn, Madjedbebe and Ngarradj Warde Djobkeng). During this period, there was extinction of at least one marsupial, Sarcophilus harrisii (Tasmanian devil) (Russell-Smith et al. 1997:178; Schrire 1982) and an increase in the formation and presumably use of open sites (predominately shell middens and earth mounds) and small rockshelters located close to permanent freshwater systems (e.g. Nauwalabila I, Jimeri I and Nawulandja) and tidal rivers (Malangangerr and Paribari) (Allen 1996:199; Brockwell 2006; Brockwell et al. 2009:61; Meehan et al. 1985:152).

\section{Archaeological research}

The area now known as Kakadu National Park has been of interest to archaeologists since the 1960s especially (Figure 5.3). Research has focused on the escarpment (e.g. Allen and Barton 1989; Jones and Negerivich 1985; Schrire 1982) as well as the floodplains (e.g. Brockwell 1996; Hiscock et al. 1992; Meehan et al. 1985; Woodroffe et al. 1988). Detailed overviews of archaeological research in Kakadu are provided elsewhere (Hiscock 1999; Jones 1985). We focus here on previous archaeological, rock art and ethnographic work relating to Mirarr Country and, where possible, specifically to Madjedbebe.

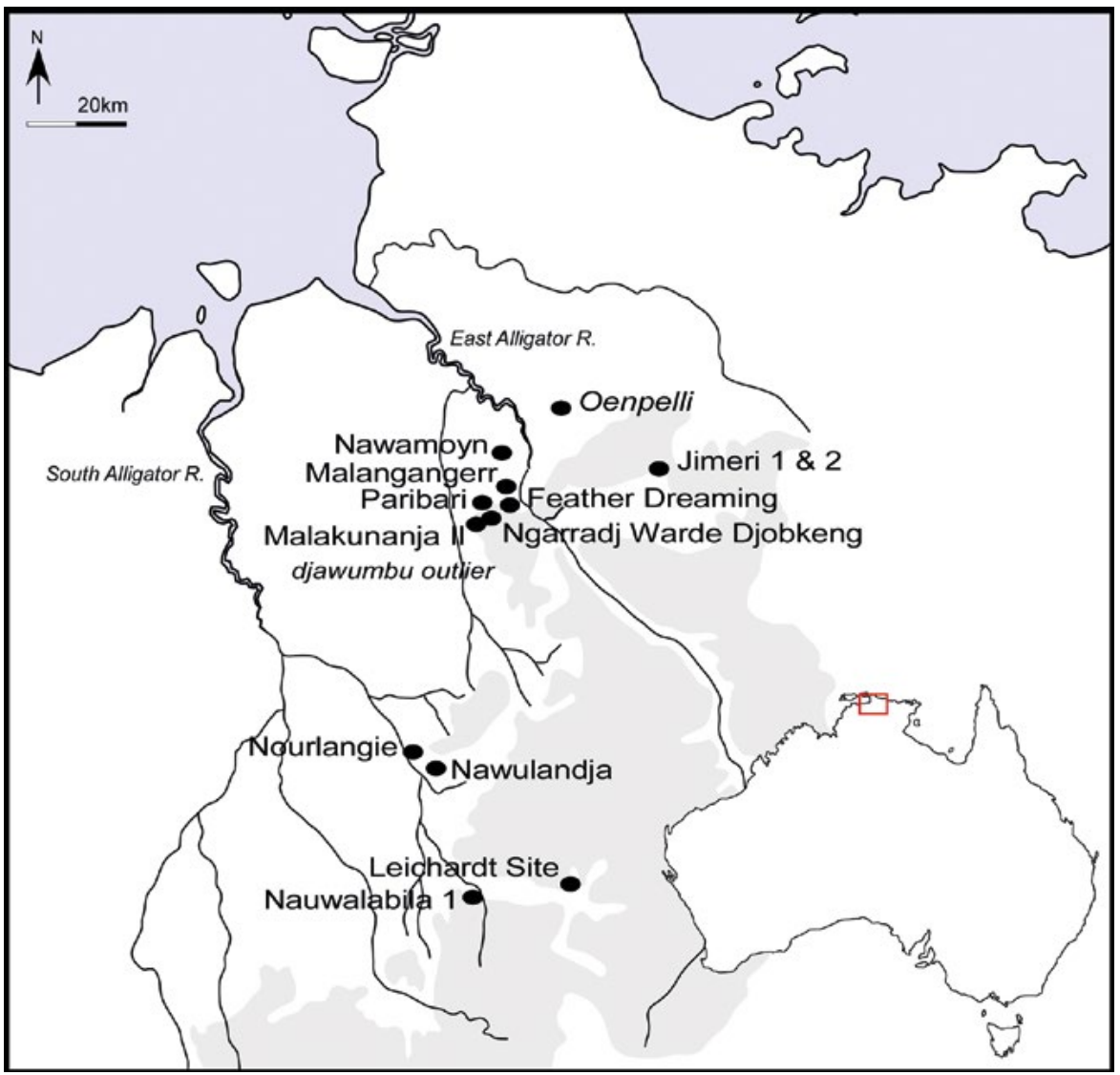

Figure 5.3 Distribution of key rock art and other archaeological sites mentioned in this chapter. The grey area marks the escarpment, also known by local Aboriginal people as 'Stone Country'. Source: Duncan Wright. 
White (now Schrire) conducted the first major scientific archaeological study in Mirarr Country and surrounds during the 1960s (Schrire 1982; White 1967a, 1967b, 1967c, 1971). Her rockshelter excavations targeted the lower slopes of small plateau outliers (Nawamoyn, Paribari and Malangangerr) and the plateau valleys (Tyimede or Jimerri I and II) (Figure 5.3). At Malangangerr and Nawamoyn, a (primarily estuarine) shell midden was dated to 7000-6000 BP and capped sandy layers dated to 23,000-18,000 BP (Schrire 1982:230; White 1967a:191253). Pieces of ochre, many with striations suggesting use-wear, were recorded in the Pleistocene deposits (Schrire 1982:103). A chronostratigraphic transition or interface was observed after 6000-4000 BP, from flaked core tools, steep-edged scrapers, utilised flakes, small edge-ground axes to unifacially and bifacially flaked stone points, small rectangular scrapers/adzes, bone points and shell scrapers (Schrire 1982:239; White 1971:145-67). Excavations at Paribari revealed estuarine shell midden, wooden tools and ethnobotanical materials (i.e. fragments of basket, string, bone, shell, resin and plant remains) dating within the past 3000 years. At plateau valley sites Jimeri I and II, radiocarbon dates cluster within the past 7000 years, with a single, earlier date of 10,790 \pm 200 BP from the base of Jimeri I (Schrire 1982:229).

Schrire (1982:231-234) suggests that the Arnhem Land cultural assemblages she studied were intimately linked with environmental change, particularly relating to formation of estuarine and freshwater landscapes within the past 7000 years. There was also archaeological evidence for seasonality of site use, which she interpreted as suggesting that floodplain sites were mainly visited during dry (and end of wet) seasons while plateau sites were occupied year-round (Schrire 1982:251-252).

Later, large-scale archaeological surveys of Mirarr Country were undertaken as part of the Alligator Rivers Environmental Fact-Finding Study (Christian and Aldrick 1977:1). Kamminga and Allen (1973) were commissioned to undertake the archaeological surveys, while Edwards $(1978,1979)$ focused on Aboriginal art.

Kamminga and Allen (1973) conducted their extensive survey on outliers, valleys and escarpment margins between the South Alligator and East Alligator Rivers. More than 120 sites were recorded, mostly rockshelters situated along the edges of the plateau outliers between Cannon Hill and the Djawumbu (Djawumba) massif (Kamminga and Allen 1973:iv). Six rockshelters (DJAW 1-6) were directly associated with the base or lower slopes of the Djawumbu massif.

Kamminga and Allen (1973) undertook eight test excavations on plateau outliers (Nawamoyn, Malangangerr, Ngarradj Warde Djobkeng, Feather Dreaming, Madjedbebe and Nourlangie) and in plateau valleys (Leichhardt, Nauwalabila I and Disturbed Site) (Figure 5.3). They suggested settlement at Malanganger, Madjedbebe and Nauwalabila I from 24,000-20,000 BP (Kamminga and Allen 1973:27, 48, 95). Pieces of red and yellow ochre were associated with Pleistocene deposits at Nauwalabila I, Nourlangie and Madjedbebe. Grinding stones were also found in Pleistocene deposits at Malangangerr and Nawamoyn rockshelters, with one stone from Madjedbebe impregnated with red and white ochre (Kamminga and Allen 1973:48-49). Midden deposits at Malangangerr, Madjedbebe, Ngarradj Warde Djobkeng and Nawulandja all dated after 7000 years ago, interspersed at Ngarradj Warde Djobkeng and Madjedbebe with human remains (Gillespie and Temple 1976:100; Kamminga and Allen 1973:31). Allen (1987:7) argued that Ngarradj Warde Djobkeng and Madjedbebe were 'valuable rock shelters close to the tidal flats' during the estuarine phase. However, the change from estuarine to freshwater conditions affected their usefulness and both sites appear to have been rarely used during the past few hundred years. A burial pit cut into midden shell at Madjedbebe was dated to $450 \pm 80$ BP, suggesting late Holocene funerary activity in the upper deposits of the Djawumbu outlier (Kamminga and Allen 1973:31; see also Gillespie and Temple 1976:100). 
Subsequent excavation and sand auguring allowed Rhys Jones and colleagues to re-date Madjedbebe and Nauwalabila I (Roberts et al. 1990a, 1998). The earliest occupation layer at Nauwalabila I was dated with Optically Stimulated Luminescence (OSL) to between 53,400 \pm 5400 and 60,300 \pm 6700 years ago, while thermoluminescence (TL) determinations from Madjedbebe suggested an antiquity of between 45,000 \pm 9000 and 61,000 $\pm 13,000$ years ago (Roberts and Jones 1994; Roberts et al. 1990a:154, 1998:20). Hiscock (1990) and Bowdler (1990) questioned these long chronologies, citing large standard errors for the TL dates and the possibility that cultural materials had moved through the loose, sandy sediment into older deposits. Roberts et al. (1990b, 1990c) defended their original dates, citing the good chronostratigraphic integrity of the dates, consistency between upper radiocarbon and TL determinations, and the flat (rather than angled or vertical) positions of lithics. Recently reported excavations at the site returned dates for cultural levels going back to c. 65,000 years ago, and a larger and more diverse artefact assemblage than reported from previous excavations; analysis is ongoing (Clarkson et al. 2017).

\section{Rock art surveys}

In contrast to the excavation and lithic-based archaeology, early rock art surveys of Mirarr Country did not adequately document the extent or significance of the art. For instance, given the high level of detail provided in the archaeological report for the 1973 Alligator Rivers study, the rock art results are largely understated and not based on any systematic survey methods or analytical processes. It appears as though Edwards' $(1978,1979)$ assessments of significance were based largely on the number of sites at each location, rather than on the importance of the imagery at each site, such as rare depictions or diversity of styles.

Pancontinental Mining Ltd soon afterwards commissioned its own study of the rock art of the Jabiluka Leasehold area with work undertaken by company employee A.W. Morley (1979; Morley and Lovett 1980). The reports identified numerous sites, but interpretations were limited and sometimes problematic. Many site locations were provided to Morley by the Museum and Art Gallery of the Northern Territory, based on earlier work by Chaloupka. Chaloupka had been walking Country and recording rock art sites in this region since the early 1970s as part of his wider regional surveys that were to expand in the following decades (see, for example, Chaloupka 1993, 1984a, 1984b; Chaloupka et al. 1985).

In more recent years, little systematic rock art survey and recording work has taken place in Mirarr Country, although photographs of Mirarr rock art have been published in general rock art books relating to Kakadu, and there are certainly unpublished records of Mirarr sites in private collections and individual researchers' archives.

\section{Ethnographic evidence of site use}

Only fragmentary ethnographic information has been recorded for sites in Mirarr Country, but the records do reveal some interesting insights into site use and seasonality. For instance, Layton (1981) undertook research into traditional foraging and camping patterns, as well as aspects of rock art as part of the Alligator Rivers Stage 2 Land Claim. His report summarises earlier ethnographic and anthropological findings for the area and incorporates new discussions with Elders. In his report, he relies heavily on Nakodjok (recently deceased, so his skin name is used here out of respect and cultural convention), Toby Kangele (Gangali) and Bill Nayidji (Neidji) three now-deceased senior Traditional Owners who were widely recognised as knowledgeable men of the region. Of particular interest is Layton's assertion that, 'The seasons have a major influence 
on camping patterns'. For example, 'at Narradj Warde Djobkeng shelter ... [Nayinggul] told me that people went there to camp at the beginning of the Wet and stayed there as long as there was water to drink' (1981:9). Likewise, Nayinggul suggested that 'when it started to get dry people left the rock shelters and went to a sand ridge or, for example, Djabiluku billabong' (Layton 1981:9). Overall, Layton surmises that people generally moved towards the escarpment with the coming of the wet and then retreated as water resources dried up. While he does not individually name the site of Madjedbebe, several nearby large areas are specifically referred to as either wet season or dry season camps by the Elders. These sites include Narradj Warde Djobkeng, Djawumbu and Madjawarrnja as wet season camps (Layton 1981:10). Importantly, he further questioned the Elders about their movements away from these camps at different times of the year:

On the 16th of December at Mawundaddjawu, a wet season camp ... I asked [Nakodjok] whether people stayed in one camp for the duration of the Wet Season. He replied that people would get bored sitting in one place: People moved along the foot of the escarpment, or to Oenpelli, or up onto the top of the escarpment hunting for wallaby, or out onto the flooded plain. (Layton 1981:11).

Senior Mirarr Elder Toby Gangali (Figure 5.4) provided further insights into camp life:

Toby says of Barribarri, 'it was just a different camp - we never used to sit; if there was no game, no goanna or anything, we used to shift to other place. All the time we kept moving around'. In conversation, Toby told me that people could stay about one week at a particular camp. When the game had been frightened away, it was time to move to the next one. (Layton 1981:13).

Gangali also suggested that 'a man walking alone could cover ten to twenty miles in a day, but a family travelling with children would only travel five to six miles between camps' (Layton 1981:14). For Djawumbu, Gangali suggested it was a camping place mainly for Mirarr, Dadjbaku and Bunidj, and that 'they went there to get away from mosquitoes and for ceremonies' (Layton 1981:17).

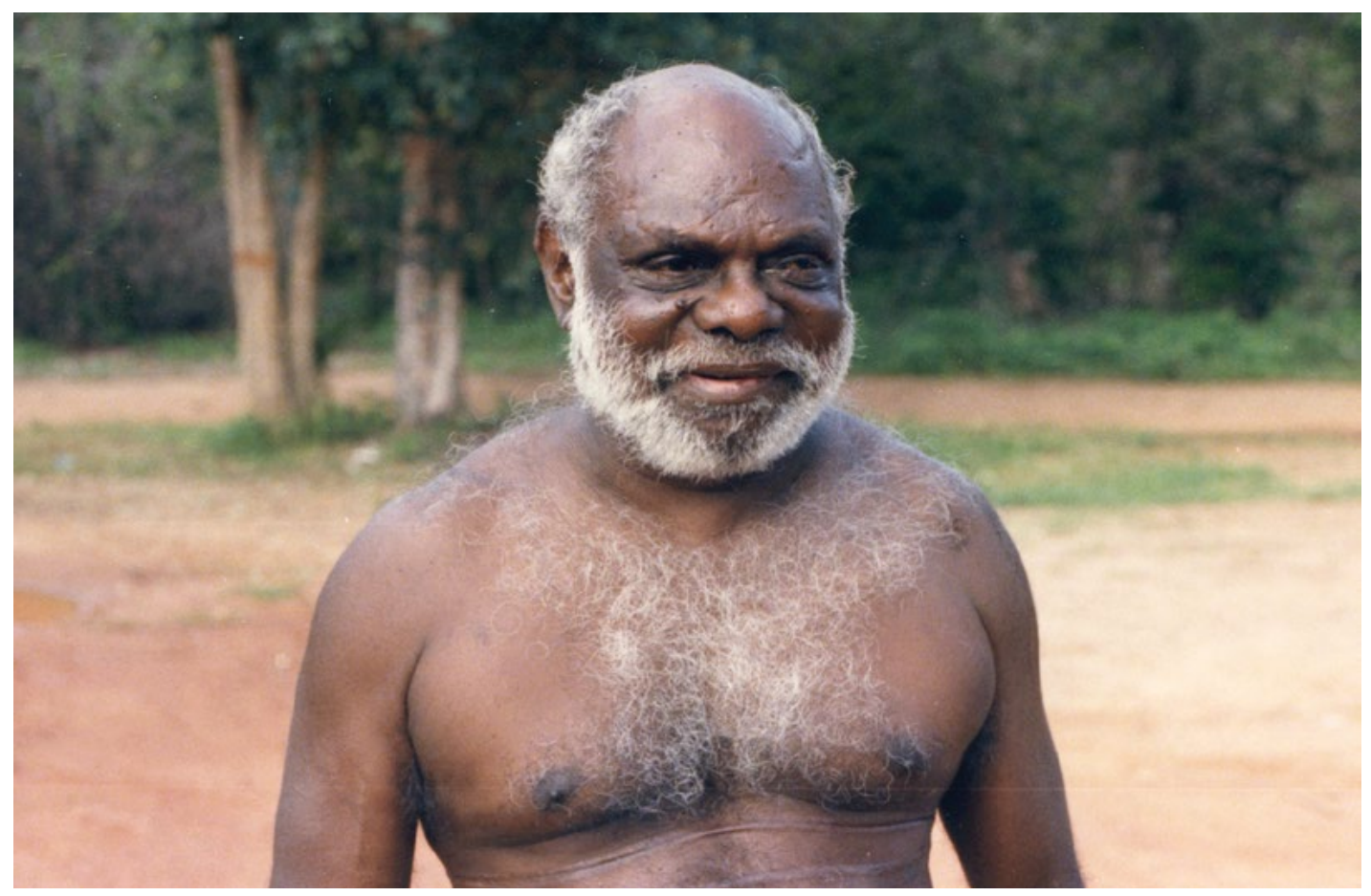

Figure 5.4 Toby Gangali in 1985.

Source: Photograph by Paul Taçon. 
Gangali also includes Djawumbu in his description of walking routes, in particular a route between the European contact-period sites of Oenpelli and Baroalba Timber Camp (Layton 1981:19; see also Kamminga and Allen 1973:44, 53). While he is clearly describing walking routes used in the European-contact period, many such routes would have followed earlier, pre-contact seasonal movements, making use of known rockshelters and water sources along the way.

In the same year as Layton (1981) produced his report, Chaloupka (1981) published a brief article titled 'The traditional movement of a band of Aboriginals in Kakadu'. In this work, he documented the movements of members of the Badmardi clan across many different territories including Mirarr Country. He states that after leaving the Djabiluku waterhole, the group 'followed the Djawumbu-Madjawarnja outlier past the knob-tailed gecko, the mosquito egg, paperbark raft, and dog Dreaming sites on to the plains of the many-braided Magela Creek' (Chaloupka 1981:169). This clearly places the Madjedbebe site along the walking route of this other clan group and suggests that the Mirarr regularly hosted other clan groups in their Country. Chaloupka (1981:162) explains why the Badmardi regularly made these trips:

Although the food resources of their valley were quite plentiful, the members of this clan visited the territories of nearby groups to share in the seasonal bounty of certain animal species such as the magpie geese and file snakes, and to collect materials not available in their own land.

The collecting of materials for tools, fabric and weapons outside the clan group are also mentioned in other ethnographic sources (Berndt and Berndt 1970). Importantly, such journeys were not just about acquiring resources, but were linked to marriage, trade, ceremony and the instruction of youths in traditional law and cultural stories.

With this background and context in mind, we now turn to the rock art of Madjedbebe.

\section{The rock art at Madjedbebe}

Fieldwork for the Mirarr Gunwarddebim project began in 2012 as part of a five-year project. Armed with general information on previous site surveys, an intensive field survey methodology was adopted and, with the assistance of a $500 \mathrm{~m} \times 500 \mathrm{~m}$ grid system, teams walked the entire study area, which is the Jabiluka Leasehold.

To document the sites, a three-stage process was adopted. Basic information was recorded for every site, including location, the presence of rare or unusual rock art and management/ conservation recommendations. This was followed by the collection of more specialised data relating to the site, the rock art and conservation issues. Some sites were chosen for full detailed site recording based on the number of images located within a site, and elements contained within individual paintings.

Of the 528 sites recorded from 2012 to 2014, two were selected for detailed recording, including Madjedbebe. At each of these rockshelters, a full detailed inventory was made of the art including description, colour, style, condition, scaled and unscaled photographs and measurements for each figure. Scenes were recorded as single images.

\section{The rock art assemblage}

A total of 1068 individual images were recorded at Madjedbebe over a three-week period. Given that many other images probably once existed but have either been buried by sediments, deteriorated and disappeared over time, or been painted over and totally obscured by newer artworks, this number of recorded images should be seen as a minimum number of the original corpus of artworks. Today, the art stretches from one end of the shelter to the other, a distance of nearly $50 \mathrm{~m}$ (Figures 5.5 and 5.6). Artworks are often superimposed over each other, with many layers of art being evident. The following is a general description of the Madjedbebe rock art.

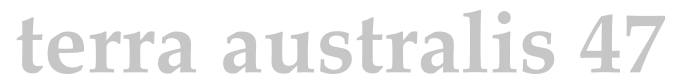




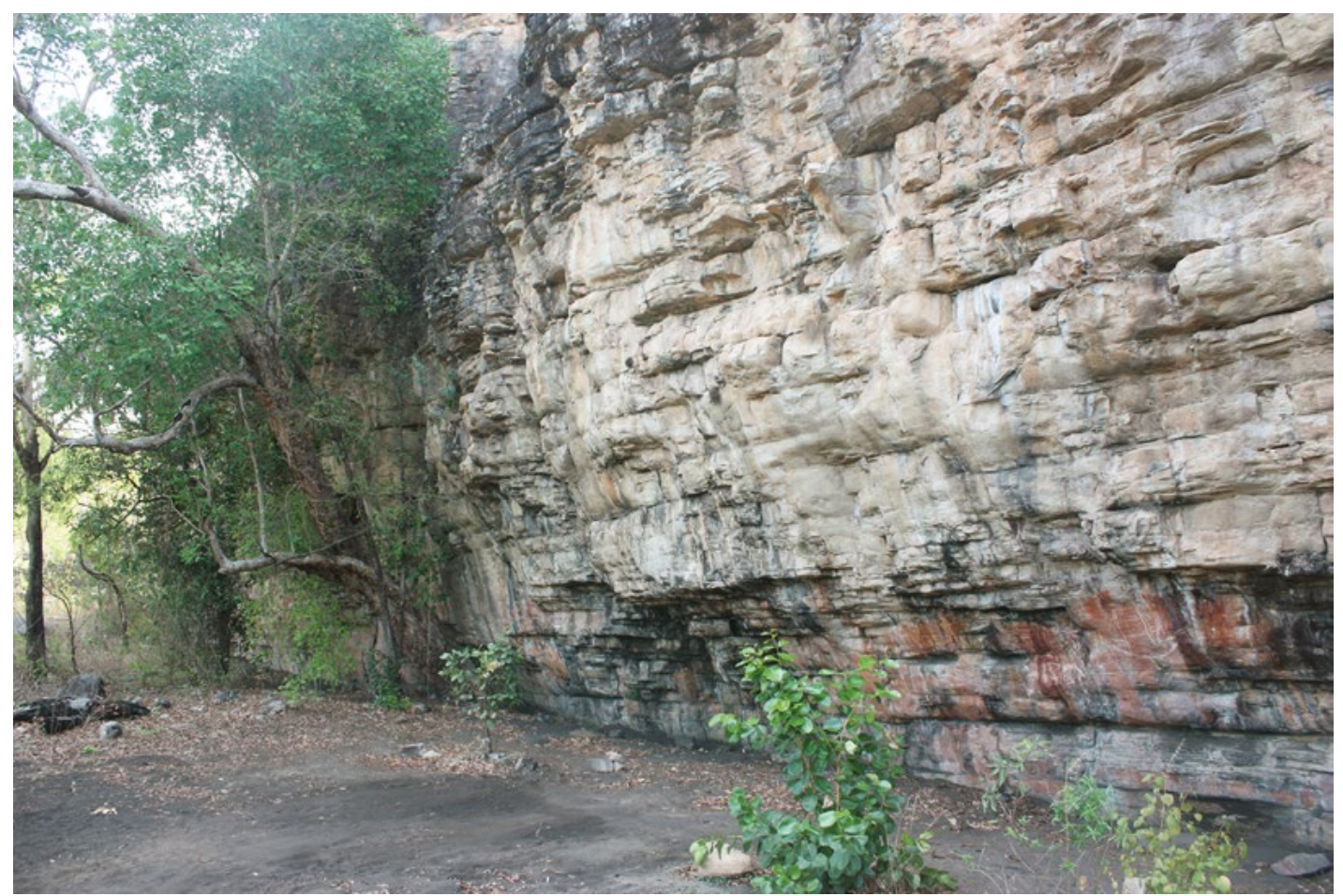

Figure 5.5 View of some of the painted panels at Madjedbebe, 2012.

Source: Photograph by Sally K. May.

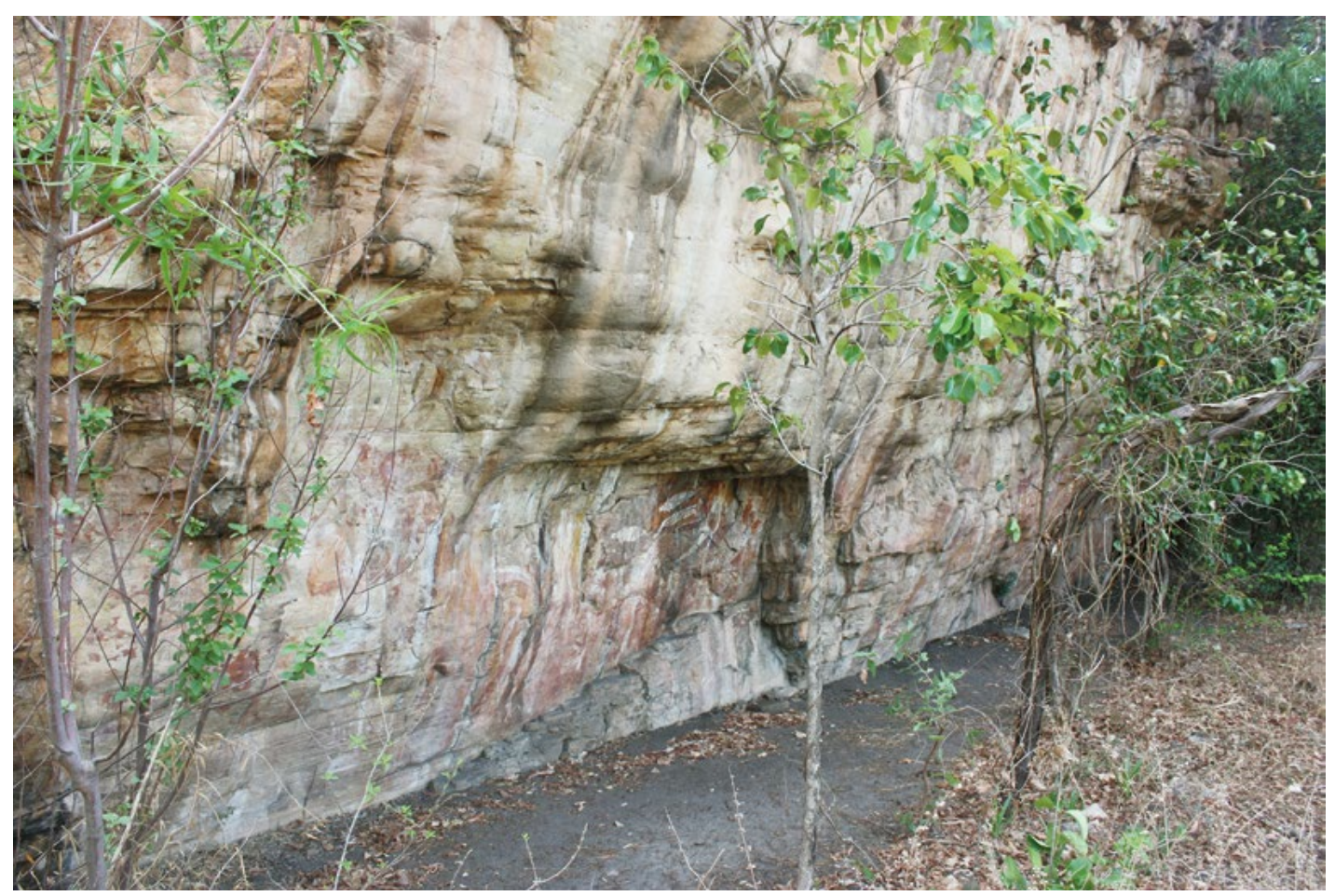

Figure 5.6 View of some of the painted panels at Madjedbebe, 2012.

Source: Photograph by Sally K. May. 


\section{Technique and colour}

Of the 1068 surviving images at this site, 894 ( 83.7 per cent) are paintings, 128 (12 per cent) are stencils, 28 (2.6 per cent) are beeswax figures and 18 (1.7 per cent) are charcoal drawings. While the proportional representation of each technique is relatively standard for the Arnhem Land region, the overall number of individual images makes this one of the most prolifically painted sites in the area. Given the shallow overhang and therefore partial exposure of the rock surface, it is surprising to find so many images, possibly suggesting that the site was once home to a much larger rock art corpus. Furthermore, feral animals have severely damaged or destroyed the lower rock art by rubbing against the surface of the shelter. For this latter reason, little art survives less than $1 \mathrm{~m}$ above ground level.

A broad range of ochre colours and mineralogies are represented within the painting assemblage, with a predominance of red haematite ( $\mathrm{n}=256$ images), white kaolin clay $(\mathrm{n}=144)$ and yellow ochre $(n=138)$ (Table 5.1). The overall broad range of colours is not unusual for this region and may be partly due to the nature of the composition of the pigments and the binding agents used in their preparation. The high number of images using white may also be attributed to the interpreted age of the paintings that, based on stylistic analysis, fall within the most recent phases of the rock art chronology of Arnhem Land. While preferential preservation may be a key factor in the predominance of red images (red ochre is known to sometimes form a strong bond with the rock surface), ethnographic and archaeological research in this region also suggests a high level of cultural significance for the colour red (Taylor 1996).

Table 5.1 Colours and colour combinations used to produce rock paintings at Madjedbebe.

\begin{tabular}{|l|r|}
\hline Colour & Number of images \\
\hline Red & 256 \\
\hline White & 144 \\
\hline Yellow & 138 \\
\hline Red and white & 121 \\
\hline Purple & 73 \\
\hline Red and yellow & 64 \\
\hline Black & 34 \\
\hline Purple and yellow & 20 \\
\hline Purple and white & 19 \\
\hline Red, white and yellow & 7 \\
\hline Black and red & 3 \\
\hline Purple and red & 3 \\
\hline Purple, red and white & 3 \\
\hline White and yellow & 3 \\
\hline Purple, red and yellow & 2 \\
\hline Black and white & 1 \\
\hline Brown & 1 \\
\hline Gray & 1 \\
\hline Purple, white and yellow & 1 \\
\hline Black and yellow & 1 \\
\hline
\end{tabular}

Source: Authors' data.

\section{Subject matter}

Interpreting rock art subject matter is often speculative, not least in an early stage of any project, so here we take a conservative approach to the interpretation of the many images at Madjedbebe. In short, we take a descriptive approach and do not speculate on deeper meanings. One important reason for this approach is that there is ample ethnographic evidence to suggest Aboriginal artists working on both bark and rock in western Arnhem Land concealed multi-layered meanings in their works. Luke Taylor's (1996) work with artists in the 1980s highlighted that apparently 'simple' paintings (such as fish) were more often than not imbued with 'inside' knowledge that artists were communicating to initiated individuals. Taçon (1989) found this was also true of recent rock art. In other words, depending on your cultural standing, paintings hold different meanings to different people (May 2008:171-194). Our overview for this chapter, therefore, presents only the 'outside' or public stories behind the rock art.

In common with many rock art sites across the region (e.g. Chaloupka 1993), there is a predominance of human-like figures (22 per cent) and geometric designs (16 per cent) at this site (Table 5.2). Many of 
the paintings could not be allocated an image form because of their poor condition or superimposition by subsequent art.

Of interest is the high proportion of disarticulated human-like figures and paintings of bundled bones $(\mathrm{n}=26)$ at the site (Figure 5.7). In addition to the paintings, 128 stencils were also recorded (Table 5.3). There is a high incidence of hand stencils, evenly spread between left $(n=38)$ and right hands $(n=35)$. There is also an unusually large number of painted hand or painted hand and forearm stencils ( $\mathrm{n}=12$; Figure 5.8).
Table 5.2 General interpretation of the painting forms at Madjedbebe.

\begin{tabular}{|l|r|}
\hline Image form & Number of images \\
\hline Unknown & 310 \\
\hline Human-like figure & 232 \\
\hline Geometric design & 177 \\
\hline Fish & 86 \\
\hline Contact & 36 \\
\hline Reptile & 28 \\
\hline Material culture & 15 \\
\hline Mammal & 4 \\
\hline Flora & 6 \\
\hline
\end{tabular}

Source: Authors' data.

Table 5.3 General interpretation of the stencils at Madjedbebe, with colours shown for the first three categories.

\begin{tabular}{|c|c|c|}
\hline Stencil type & Number of images & Colour \\
\hline Left hand & 38 & Yellow $=19$, white $=18$, Red $=1$ \\
\hline Right hand & 35 & Yellow $=17$, white $=15$, Red $=3$ \\
\hline Hand (unknown) & 9 & White $=4$, Yellow $=5$ \\
\hline Unidentified & 8 & \\
\hline Right hand and forearm & 7 & \\
\hline Left hand and forearm & 6 & \\
\hline Painted left hand and forearm & 6 & \\
\hline Finger & 5 & \\
\hline Left foot & 3 & \\
\hline Painted right hand and forearm & 3 & \\
\hline Right foot & 1 & \\
\hline Painted left hand & 1 & \\
\hline Painted right hand & 1 & \\
\hline Painted hand and forearm & 1 & \\
\hline
\end{tabular}

Source: Authors' data.

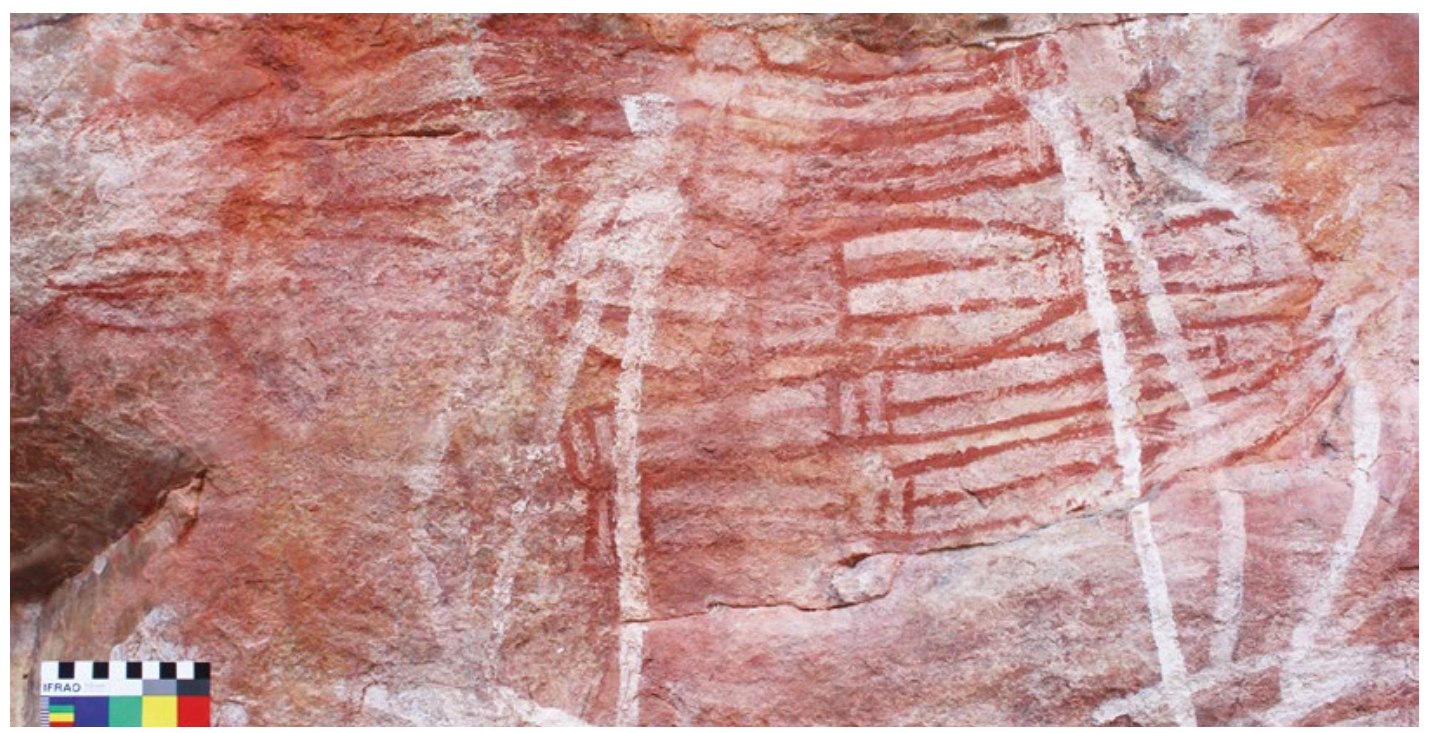

Figure 5.7 Depiction of bundled human bones at Madjedbebe, 2013.

Source: Photograph by Melissa Marshall. 


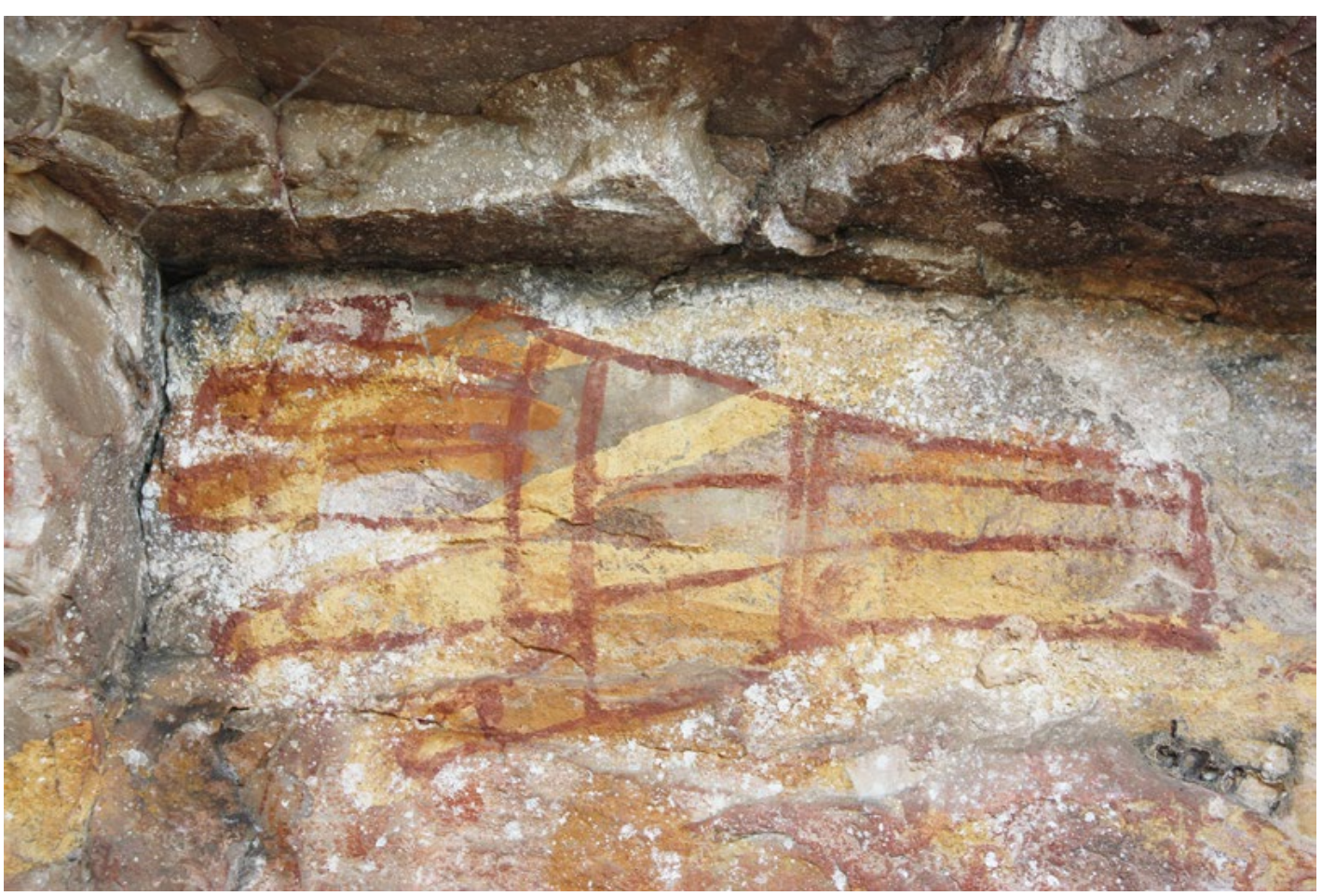

Figure 5.8 Painted hand and forearm stencil from Madjedbebe. The hand was first stencilled, then outlined and infilled.

Source: Photograph by Melissa Marshall.

Of the fish species that could be identified, catfish predominate, with 13 examples each of eeltailed and lesser salmon catfish, and two that could not be attributed to a particular taxon (Table 5.4). Also occurring in significant numbers are barramundi, freshwater long-tom, mullet and saratoga.

Table 5.4 Types of fish depicted at Madjedbebe.

\begin{tabular}{|l|l|l|r|}
\hline Fish & Gundjeihmi name & Scientific name & Number of images \\
\hline Unidentified & - & - & 23 \\
\hline Eel-tailed catfish & Binjdjarrang & $\begin{array}{l}\text { Tandanus tandanus, } \\
\text { Neosilurus ater, Neosilurus hyrtlii }\end{array}$ & 13 \\
\hline Lesser salmon catfish & Almakkawarri & Arius leptaspis & 13 \\
\hline Barramundi & Namarn.gol & Lates calcarifer & 10 \\
\hline Freshwater long-tom & Burrugulung & Stongylura kreffti & 7 \\
\hline Mullet & Madjabarr & Liza diadema and Liza dusumieri & 7 \\
\hline Saratoga & $\begin{array}{l}\text { 1. Ngaldadmo } \\
\text { 2. Guluibirr }\end{array}$ & Scleropages jardini & 6 \\
\hline $\begin{array}{l}\text { 1. Archer fish } \\
\text { 2. Primitive archer fish }\end{array}$ & $\begin{array}{l}\text { 1. Njarlgan } \\
\text { 2. Bodjdjalk }\end{array}$ & $\begin{array}{l}\text { 1. Toxotes chatareus } \\
\text { 2. Toxotes lorentzi }\end{array}$ & 2 \\
\hline Boney bream & $\begin{array}{l}\text { Nabardebarde } \\
\text { (variant: bardebarde) }\end{array}$ & Nematolosa erebi & 2 \\
\hline Catfish (type unidentified) & - & -- & 85 \\
\hline Total & & & \\
\hline
\end{tabular}

Note the unidentified fish were too poorly preserved to ascertain species.

Source: Authors' data. Gundjeihmi names provided by Murray Garde. 
Of the 894 paintings, 36 are images of subject matter from the European-contact period. This includes an unusually large number of firearms ( $n=16$; Figures 5.9 and 5.10) (May et al. 2017), as well as knives, people with hands on hips, watercraft (two ships and a row boat) and a series of smoking pipes. Other paintings featuring more traditional subject matters were identified as having been painted during the European-contact period as they are superimposed over paintings of European subject matters.

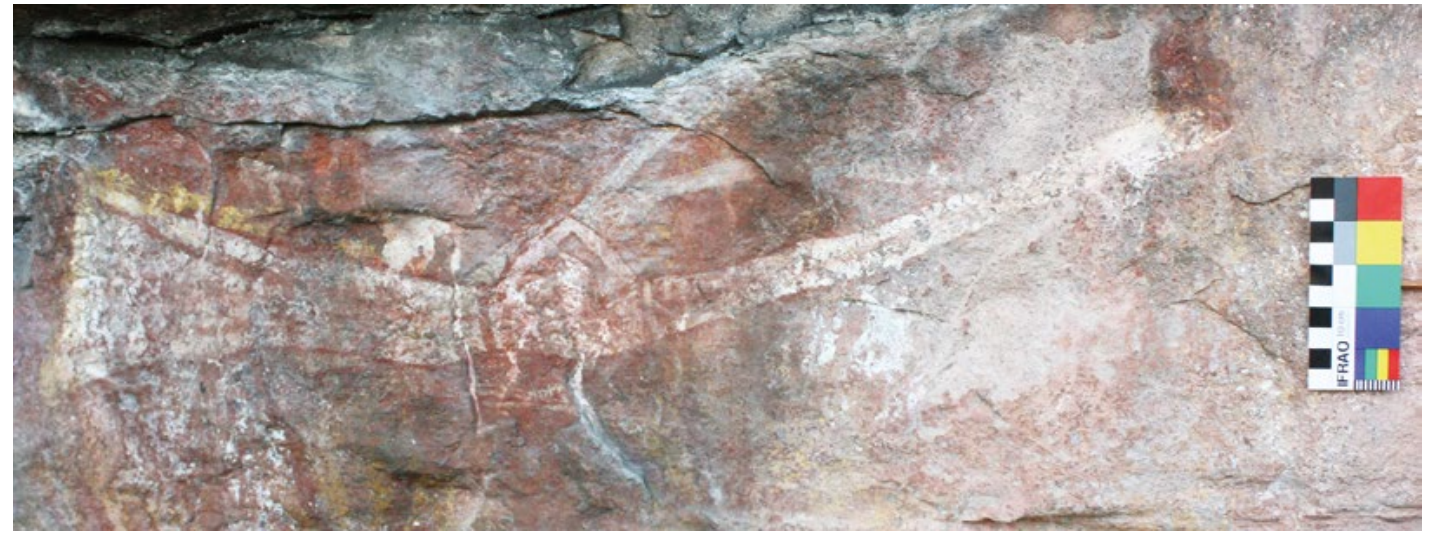

Figure 5.9 Painting of a firearm from Madjedbebe, one of 16 depicted at the site. This example is shown hanging upside down as though on the side of a horse or across the shoulder of the carrier. Source: Photograph by Melissa Marshall.

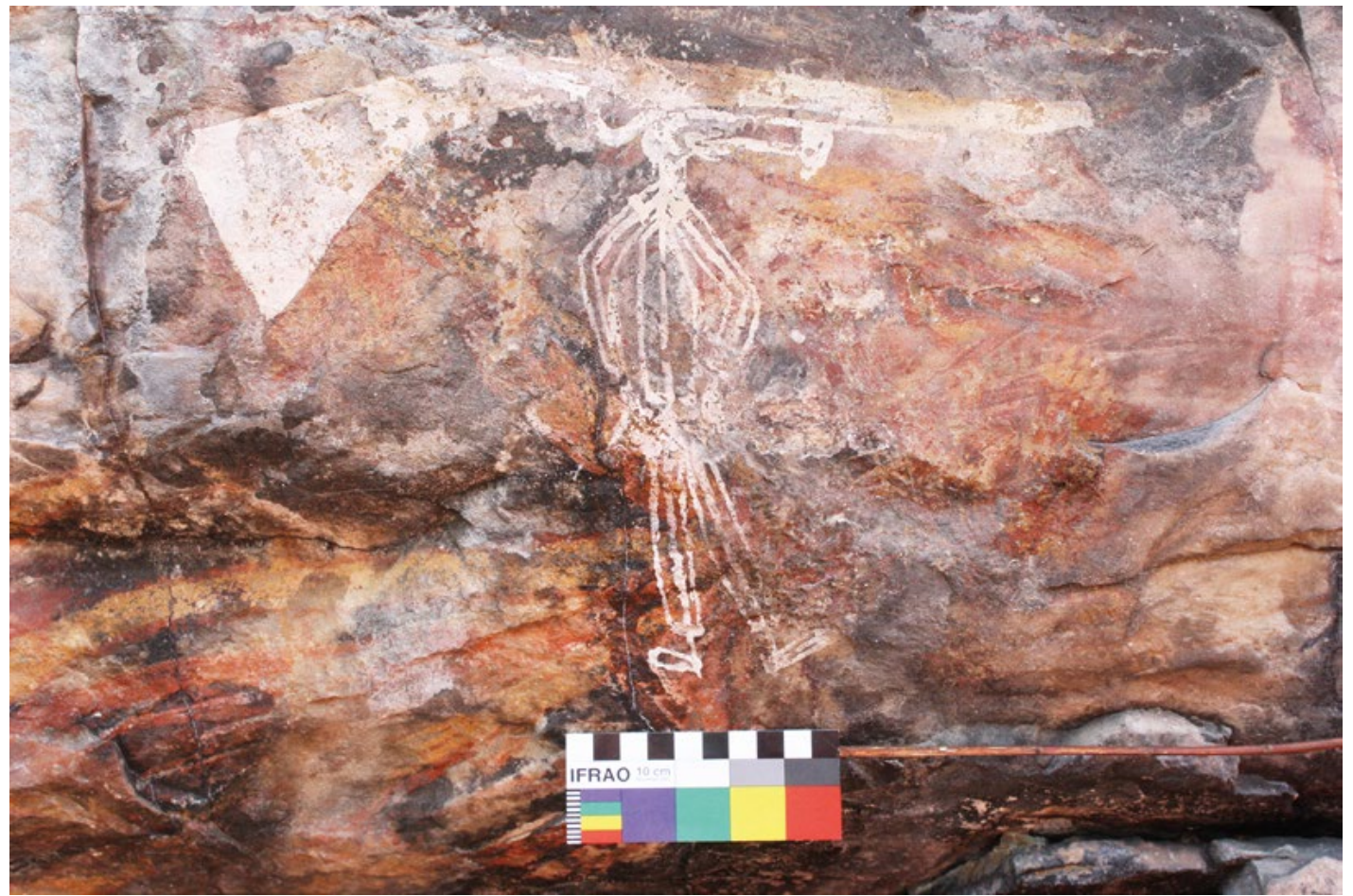

Figure 5.10 European-contact painting featuring a person wearing European-style clothing, smoking a pipe and with oversized gun depicted above head.

Source: Photograph by Sally K. May. 


\section{Style and chronology}

While a number of stylistic chronologies have been proposed for western Arnhem Land rock art (e.g. Chaloupka 1993; Chippindale and Taçon 1998; Lewis 1988), little 'direct' dating of the art has taken place (beeswax art being an exception, e.g. see Nelson 2000; Taçon et al. 2004). However, there is a range of evidence to suggest that the oldest surviving rock art of this region, including paintings of large naturalistic animals, is over 15,000 years of age and possibly as much as 30,000 years (for an example of early art, see David et al. 2013). Chaloupka (1984a, 1984b, 1993) has argued that, taken as a corpus, the rock art of western Arnhem Land illustrates significant environmental, technological and stylistic change over time. A number of sequential art styles have thus been identified by studying the superimposition of individual paintings and comparing these across many hundreds of sites (e.g. Chippindale and Taçon 1993, 1998; Lewis 1988). These studies have used depictions of extinct animals, a variety of artefact types, clothing and other types of worn paraphernalia and/or recent subject matters to mark changes in style from the pre-estuarine to estuarine, freshwater and historic periods (see Table 5.5).

Table 5.5 Proposed stylistic chronology for western Arnhem Land rock art.

\begin{tabular}{|c|c|c|c|}
\hline \multicolumn{4}{|l|}{ Pre-estuarine } \\
\hline \multicolumn{2}{|c|}{$\begin{array}{l}50,000 \text { years ago } \\
\text { From this date, haematite and red and yellow ochres } \\
\text { were used to prepare pigment }\end{array}$} & object imprints & $\begin{array}{l}\text { Hand prints; imprints of grass and other } \\
\text { thrown objects }\end{array}$ \\
\hline \multirow[t]{6}{*}{20,000 years ago } & Naturalistic & $\begin{array}{l}\text { Large naturalistic } \\
\text { figures complex }\end{array}$ & $\begin{array}{l}\text { Possible extinct megafauna; thylacine; } \\
\text { Tasmanian devil; terrestrial animals, rock } \\
\text { python; freshwater crocodile; human beings; } \\
\text { earliest x-ray paintings }\end{array}$ \\
\hline & & Dynamic figures & $\begin{array}{l}\text { Human beings in complex apparel; } \\
\text { anthropomorphs; zoomorphs; terrestrial } \\
\text { animals; freshwater fish; stencils; hand of } \\
\text { 3MF convention, boomerangs; one-piece } \\
\text { multi-barbed spears; detailed compositions }\end{array}$ \\
\hline & Stylisation & Post-dynamic figures & $\begin{array}{l}\text { Human beings in headdresses, pubic aprons } \\
\text { and bustles; macropods; lizards; fighting pick/ } \\
\text { hooked stick introduced }\end{array}$ \\
\hline & Schematisation & $\begin{array}{l}\text { Simple figures with } \\
\text { boomerangs }\end{array}$ & $\begin{array}{l}\text { Human beings in headdresses, pubic aprons } \\
\text { and bustles; conflict; fighting pick; single- and } \\
\text { multi-pronged barbed composite spears; } \\
\text { possible spearthrower }\end{array}$ \\
\hline & Stylisation & Mountford figures & $\begin{array}{l}\text { Human beings (many elongated); } \\
\text { spearthrower }\end{array}$ \\
\hline & Naturalistic symbolism & Yam figures & $\begin{array}{l}\text { Anthropomorphised yams; phytomorphised } \\
\text { animals; Rainbow Serpent; ibis; egret; short- } \\
\text { necked turtle; flying fox; long-arm prawn; } \\
\text { segmented circle symbol }\end{array}$ \\
\hline \multicolumn{4}{|l|}{ Estuarine } \\
\hline 8000 years ago & Naturalistic & $\begin{array}{l}\text { Early estuarine } \\
\text { complex }\end{array}$ & $\begin{array}{l}\text { Estuarine fish: barramundi, mullet, catfish; } \\
\text { saltwater crocodile; variety of spearthrowers }\end{array}$ \\
\hline \multirow[t]{2}{*}{4000 years ago } & & Beeswax designs & $\begin{array}{l}\text { Human beings; anthropomorphs; non- } \\
\text { figurative designs }\end{array}$ \\
\hline & $\begin{array}{l}\text { Intellectual realism and } \\
\text { contemporaneous naturalism }\end{array}$ & X-гау complex & $\begin{array}{l}\text { Lightning Man; stone-tipped spear; } x \text {-ray } \\
\text { paintings of animals and humans with } \\
\text { detailed and decorative features }\end{array}$ \\
\hline
\end{tabular}




\begin{tabular}{|l|l|l|l|}
\hline \multicolumn{2}{|l|}{ Freshwater } & & $\begin{array}{l}\text { Hook-headed human beings; magpie geese; } \\
\text { water lilies; 'goose' spears; goose-wing 'fan'; } \\
\text { didjeridu; complex spearthrower }\end{array}$ \\
\hline 1500 years ago & \multicolumn{2}{|l|}{} \\
\hline 300 years ago & & & $\begin{array}{l}\text { Macassan and European subjects; introduced } \\
\text { animals; sorcery paintings; decorated hands }\end{array}$ \\
\hline Ethnographic present & & Casual paintings & \\
\hline
\end{tabular}

'3MF' stands for three middle fingers together, with the thumb and small finger to one side. Source: After Chaloupka (1993).

The paintings recorded at Madjedbebe mostly stem from Chaloupka's (1984b, 1993) 'Freshwater' and 'Contact' periods, with some X-ray images also present (Figure 5.11). This range of paintings signals the presence of artworks over a variety of climatic and social conditions. The incidence of human-like figures is relatively high, and that of fish, reptiles and mammals notably small. With the proximity of the site to the nearby floodplain resources, a higher proportion of these latter images could arguably have been expected, if the images related mainly to food resources and/or to animals from nearby settings.

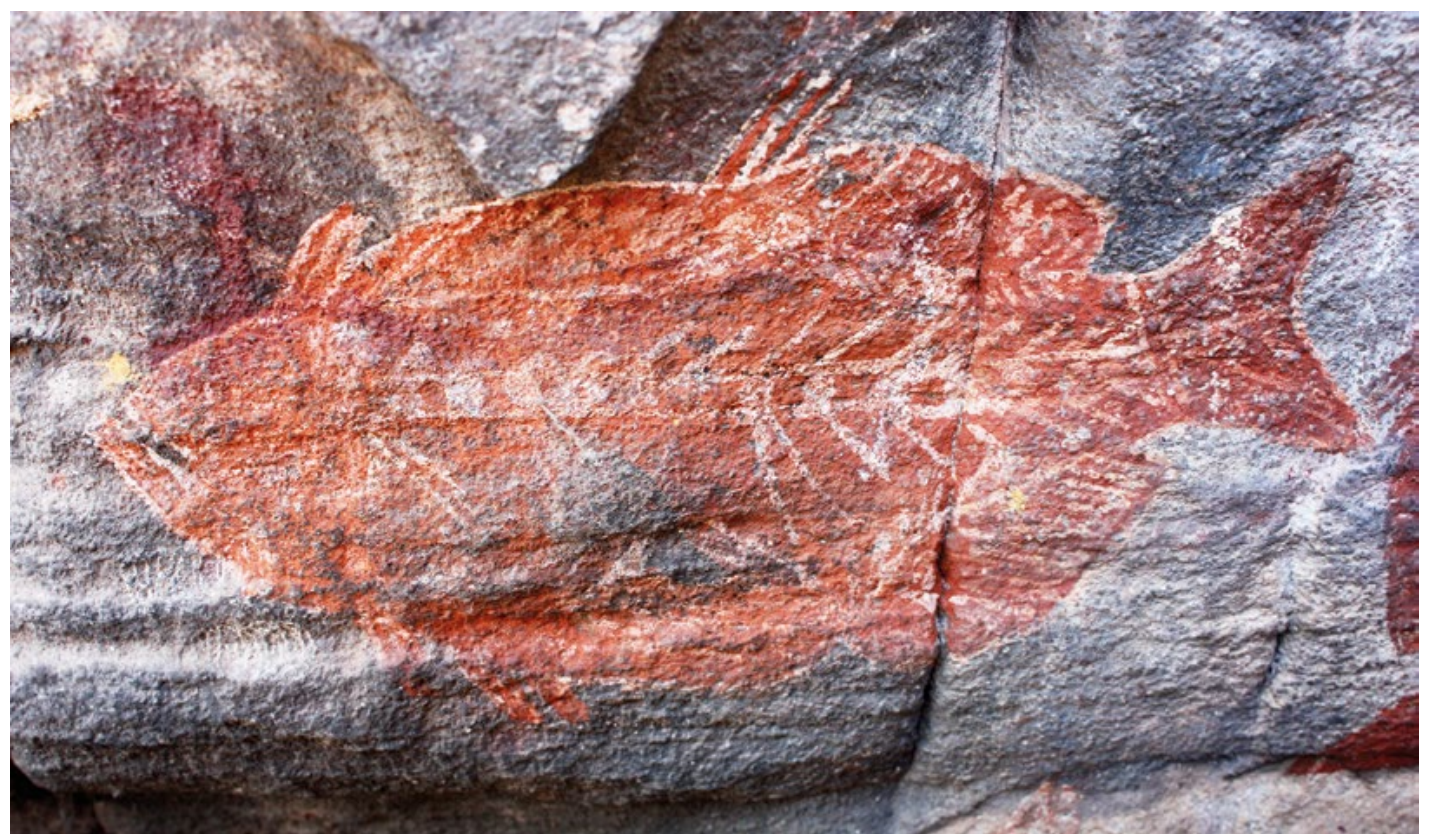

Figure 5.11 Example of an X-ray fish painting from Madjedbebe.

Source: Photograph by Joakim Goldhahn.

\section{Discussion and conclusion}

Madjedbebe may be one of the oldest dated human occupation sites in Australia, but it is also a site that remained significant to local Aboriginal people long after European incursions into the area began to disrupt and/or transform other traditional land-use patterns. It is clear from local ethnography and rock art that, at least in the recent past, this site was used as a stopping point along a dry season walking route between a number of settlements, including the Oenpelli 
Mission and buffalo shooters' camps. Artists have clearly documented some of their experiences on the walls of this bluff face, and depictions of items of high value - or, perhaps, high curiosity - such as firearms, illustrate the artists' changing lives (Figures 5.9 and 5.10) (May et al. 2017).

Evidence from other studies (e.g. May et al. 2010; Taçon et al. 2010) suggests that this walking route may have extended beyond Oenpelli to as far as the Coburg Peninsula, and that it may well have been associated with Macassan-Aboriginal, and later missionary, trade systems along the northern coastline at sites such as Anuru Bay (see, for example, Wesley et al. 2014). At the same time, European contact-period walking routes must have relied on traditional knowledge of shelter, water and food supplies, as well as alliances with neighbouring groups and movements across Country for ceremonies.

It is particularly interesting that the Madjedbebe site continued to be used into the Europeancontact period: of the 528 sites documented within the Jabiluka Leasehold, very few show clear evidence of contact rock art in the form of identifiable European-based images (e.g. Western items of material culture). Does this indicate a site of differing cultural value than others, or simply a site well positioned as a stopping point in the landscape before and after the contact period? Rockshelters offering better protection from the weather and better visibility across the landscape are available in very close proximity to Madjedbebe. As such, there must have been a cultural aspect to the preference for Madjedbebe during the European-contact period. All of these issues point to the Djawumbu massif as an important location in the landscape, both before and during contact and a site only to be adequately understood in its wider geographical and inter-cultural contexts. Most importantly, Mirarr individuals and families continue to visit Country, retaining close cultural associations with sites such as Madjedbebe.

Archaeological results demonstrate that Madjedbebe was visited during late Pleistocene and early to mid-Holocene times. The presence of haematite and other pigments, and grinding stones stained with pigment within dated archaeological deposits, support an early period of art (Clarkson et al. 2017; Kamminga and Allen 1973:48-49). However, paintings of the region's earliest identified styles, such as Dynamic and Yam Figures, have either not survived at the site, or are buried below deep deposits. At Madjedbebe and the adjacent site of Ngarradj Warde Djobkeng, shellfish middens (incorporating remains of marsupials, reptiles, birds and fish) date back to 7000 years ago, suggesting extensive site use during the estuarine phase. Allen (1987) and others (e.g. Jones 1985) argue that reduced settlement activity after 2500 years ago was due to major environmental changes and associated movements of people towards new freshwater systems. While no direct dates have been obtained for the on-wall rock art at Madjedbebe, the principal period of rock art is arguably contemporaneous with a period of reduced occupational activity at the site dating from c. 2500 years ago to present (Allen 1987). This relatively recent time period is evident through the dominance of more recent rock art styles, and the prominence of freshwater (mixed freshwater/saltwater) fish depicted in the rock art. The unusual prominence of human-like figures, disarticulated bones and deformed human figures in the art corresponds with ethnographic records for Djawumbu, suggesting that Madjedbebe may have been an important site for cultural activity during this late Holocene period. Importantly, the re-excavation of Madjebebe in 2012 revealed 17 individuals buried at this site (Lowe et al. 2014:157). Could the unusually high number of paintings of disarticulated human remains be somehow linked to the high number of actual burials at this site, or in other ways to the death of these individuals (e.g. sorcery art causing or responding to their deaths)? There is a significant relationship existing between the placement of rock art and the human remains at this site. The artists are perhaps marking this place with visual signs of cultural activities and beliefs relating to death. Further research relating to the age of the burials and the art may provide greater evidence for such relationships. 
Madjedbebe is well known for being an important site in terms of early evidence for the human settlement of Australia. Less well known, but arguably no less important, is the emerging late Holocene record of complex human activities, as demonstrated in the rock art assemblage. Work to date, including the analysis of Madjedbebe's rock art, has produced some important findings and directed us towards new research angles and lines of enquiry for the coming years.

\section{Acknowledgements}

We would like to thank the Mirarr people and the Gundjeihmi Aboriginal Corporation for working with us on the Mirarr Gunwarddebim project and, in particular, Yvonne Margarula and Justin O'Brien. Thanks are due to Energy Resources of Australia for allowing us access to the Jabiluka Leasehold area to undertake these surveys, the Kakadu National Park Natural Cultural Programs Unit for their time, assistance and ongoing support and to the Northern Land Council and Aboriginal Areas Protection Authority for permits, maps and more. Many people have contributed to the Mirarr Gunwarddebim project in various ways and we thank you for your support. We would especially like to thank volunteers Janet Davill and Jessica Blackman, who spent weeks at the sites helping to document individual images. Murray Garde (The Australian National University) kindly provided the Gundjeihmi spellings for different fish species. Finally, we thank our archaeological colleagues who, while excavating, shared the Madjedbebe space with us during much of the 2012 field season.

\section{References}

Allen, H. 1978. The Jabiluka Project: Draft Environmental Impact Statement. In G. Chaloupka (ed.), Djawumbu-Madjawarnja Site Complex: Nomination for Inclusion on the Register of the National Estate, Canberra. Unpublished report, Australian Institute of Aboriginal Studies, Canberra.

Allen, H. 1987. Holocene mangroves and middens in northern Australia and Southeast Asia. Indo Pacific Prehistory Association 7:1-16. doi.org/10.7152/bippa.v7i0.11248

Allen, H. 1996. The time of the mangroves: Changes in mid-Holocene estuarine environments and subsistence in Australia and Southeast Asia. Bulletin of the Indo-Pacific Prehistory Association 15:193-205. doi.org/10.7152/bippa.v15i0.11548

Allen, H. and G. Barton 1989. Ngarradj Warde Djobkeng: White Cockatoo Dreaming and the Prehistory of Kakadu. Oceania Monograph 37, Oceania Publications, Sydney.

Allen, J. and J.F. O'Connell 2014. Both half right: Updating the evidence for dating first human arrivals in Sahul. Australian Archaeology 79: 86-108. doi.org/10.1080/03122417.2014.11682025

Berndt, R.M. and C.H. Berndt 1970. Man, Land and Myth in North Australia. Ure Smith, Sydney.

Bourke, P., S. Brockwell, P. Faulkner and B. Meehan. 2007. Climate variability in the mid-late Holocene Arnhem Land region, north Australia: Archaeological archives of environmental and cultural change. Archaeology in Oceania 42:91-101. doi.org/10.1002/j.1834-4453.2007.tb00022.x

Bowdler, S. 1990. 50,000 year-old site in Australia - Is it really that old? Australian Archaeology 31:93. doi.org/10.1080/03122417.1990.11681394

Brockwell, S. 1996. Open sites of the South Alligator River wetland, Kakadu. In P. Veth and P. Hiscock (eds), Archaeology of Northern Australia, pp. 90-105. Tempus 4. Anthropology Museum, University of Queensland, St Lucia. 
Brockwell, S. 2006. Earth mounds in northern Australia: A review. Australian Archaeology 63:47-56. doi.org/10.1080/03122417.2006.11681837

Brockwell, S., R. Levitus, J. Russell-Smith and P. Forrest 1995. Aboriginal Heritage. In A.J. Press, D. Lea, A. Webb and A. Graham (eds), Kakadu Natural and Cultural Heritage and Management, pp. 15-63. Australian Nature Conservation Agency, North Australia Research Unit, The Australian National University, Canberra.

Brockwell, S., P. Faulkner, P. Bourke, A. Clarke, C. Crassweller, D. Guse, B. Meehan and R. Sim. 2009. Radiocarbon dates from the Top End: A cultural chronology for the Northern Territory coastal plains. Australian Aboriginal Studies 1:54-76.

Chaloupka G. 1981. The traditional movement of a band of Aboriginals in Kakadu. In T. Stokes (ed.), Kakadu National Park Education Resources, pp. 162-171. Australian National Parks and Wildlife Service, Canberra.

Chaloupka, G. 1984a. Rock Art of the Arnhem Land Plateau: Paintings of the Dynamic Figures Style. Unpublished report for the Northern Territory Museum of Arts and Sciences, Darwin.

Chaloupka, G. 1984b. From Palaeoart to Casual Paintings: The Chronological Sequence of Arnhem Land Plateau Rock Art. Northern Territory Museum of Arts and Sciences Monograph Series, Darwin.

Chaloupka, G. 1993. Journey in Time: The World's Longest Continuing Art Tradition. Reed, Chatswood.

Chaloupka, G., N. Kapirigi, B. Nayidji and G. Namingum 1985. A Cultural survey of Balawurru, Deaf Adder Creek, Amarrkananga, Cannon Hill and the Northern Corridor. Unpublished report for Museum and Art Galleries Board of the Northern Territory, Darwin.

Chappell, J. and J. Grindrod 1983. Chenier plain formation in northern Australia. In B.G. Thom (ed.), Recent Advances in Australian Coastal Studies, pp. 197-231. Academic Press, New York.

Chappell, J. and N.J. Shackleton 1986. Oxygen isotopes and sea level. Nature 324:137-140. doi. org/10.1038/324137a 0

Chippindale, C. and P.S.C. Taçon 1993. Two old painted panels from Kakadu: Variation and sequence in Arnhem Land rock art. In J. Steinbring, A. Watchman, P. Faulstich and P.S.C. Taçon (eds), Time and Space: Dating and Spatial Considerations in Rock Art Research, pp. 32-56. Australian Rock Art Research Association, Melbourne.

Chippindale, C. and P.S.C. Taçon 1998. The many ways of dating Arnhem Land rock-art, north Australia. In C. Chippindale and P.S.C. Taçon (eds), The Archaeology of Rock-Art, pp. 90-111. Cambridge University Press, Cambridge.

Christian, C.S. and J.M. Aldrick 1977. Alligator Rivers Study: A Review Report of the Alligator Rivers Region Environmental Fact-Finding Study. Australian Government Publishing Service, for the Department of Northern Territory and the Australian Mining Industry Council, Canberra.

Clark, R.L. and J.C. Guppy 1988. A transition from mangrove forest to freshwater wetland in the monsoon tropics of Australia. Journal of Biogeography 15:665-84. doi.org/10.2307/2845444

Clark. R.L., J. Guppy, D. Mahon, P. McBride and R.J. Wasson 1992. Late Quaternary evolution of the Magela Plain. In R.J. Wasson (ed.), Modern Sedimentation and Late Quaternary Evolution of the Magela Creek Plain, pp. 28-80. Research Report 6. Supervising Scientist of the Alligator Rivers Region, Australian Government Printer, Canberra. 
Clarkson, C., Z. Jacobs, B. Marwick, R. Fullagar, L. Wallis, M. Smith, R.G. Roberts, E. Hayes, K. Lowe, X. Carah, S.A. Florin, J. McNeil, D. Cox, L. J. Arnold, Q. Hua, J. Huntley, H.E.A. Brand, T. Manne, A. Fairbairn, J. Shulmeister, L. Lyle, M. Salinas, M. Page, K. Connell, G. Park, K. Norman, T. Murphy and C. Pardoe 2017. Human occupation of Australia by 65,000 years. Nature 547(7663): 306-310 doi.org/10.1038/nature22968

David, B., B. Barker, F. Petchey, J.-J. Delannoy, J.-M. Geneste, C. Rowe, M. Eccleston, L. Lamb and R. Whear 2013. A 28,000 year old excavated painted rock from Nawarla Gabarnmang, northern Australia. Journal of Archaeological Science 40(5):2493-2501. doi.org/10.1016/j.jas.2012.08.015

Davidson, I. and W. Noble 1992. Why the first colonisation of the Australian region is the earliest evidence of modern human behaviour. Archaeology in Oceania 27(3):135-142. doi.org/10.1002/ j.1834-4453.1992.tb00297.x

Edwards, R. 1978. Rock art in the Alligator Rivers Region. Aboriginal News 3(3):9-12.

Edwards, R. 1979. Australian Aboriginal Art: The Art of the Alligator Rivers Region, Northern Territory. Australian Institute of Aboriginal Studies 15 (new series). Australian Institute of Aboriginal Studies, Canberra.

Faulkner, P. 2009. Focused, intense and long-term: Evidence for Granular Ark (Anadara granosa) exploitation from late Holocene shell mounds of Blue Mud Bay, northern Australia. Journal of Archaeological Science 36:821-834. doi.org/10.1016/j.jas.2008.11.005

Gillespie, R. and R.B. Temple 1976. Sydney University natural radiocarbon measurements III. Radiocarbon 18:96-109. doi.org/10.1017/S0033822200002393

Hays-Gilpin, K. 2004. Ambiguous Images: Gender and Rock Art. Rowman Altamira, Lanham.

Hiscock, P. 1990. How old are the artefacts in Malakunanja II? Archaeology in Oceania 25(3):122-124. doi.org/10.1002/j.1834-4453.1990.tb00242.x

Hiscock, P. 1999. Holocene coastal occupation of western Arnhem Land. In J. Hall and I. McNiven (eds), Australian Coastal Archaeology, pp. 91-103. Research Papers in Archaeology and Natural History 31. ANH Publications, The Australian National University, Canberra.

Hiscock, P., F. Mowat and D. Guse 1992. Settlement patterns in the Kakadu wetlands: Initial data on site size and shape. Australian Aboriginal Studies 2:84-89.

Hope, G.S., P.J. Hughes and J. Russell-Smith 1985. Geomorphological fieldwork and the evolution of the landscape of Kakadu National Park. In R. Jones (ed.), Archaeological Research in Kakadu National Park, pp. 229-240. Special Publication 13. Australian National Parks and Wildlife Service, Canberra.

Johnson, I. and R. Jones 1985. Fieldwork methods. In R. Jones (ed.) Archaeological Research in Kakadu National Park, pp. 31-37. Special Publication 13. Australian National Parks and Wildlife Service, Canberra.

Jones, R. 1969. Fire-stick farming. Australian Natural History 16:224-228.

Jones, R. (ed.) 1985. Archaeological Research in Kakadu National Park, Special Publication 13. Australian National Parks and Wildlife Service, Canberra.

Jones, R. and T. Negerivich 1985. A review of previous archaeological work. In R. Jones (ed.), Archaeological Research in Kakadu National Park, Special Publication 13, pp. 1-16. Australian National Parks and Wildlife Service, Canberra.

Jones, R., T. Osborn and K. Briffa 2001. The evolution of climate over the last millennium. Science 292:662-667. doi.org/10.1126/science.1059126 
Kamminga, J. and H. Allen 1973. Alligator Rivers Environmental Fact-Finding Study: Report of the Archaeological Survey. Government Printer, Darwin.

Keen, I. 1980. The Alligator Rivers Stage II Land Claim. Unpublished report for the Northern Land Council, Darwin.

Lambeck, K. and J. Chappell 2001. Sea level change through the last glacial cycle. Science 292:679-686. doi.org/10.1126/science.1059549

Layton, R. 1981. Statement on the Alligator Rivers Stage Two land Claim: (1) Traditional Foraging and Camping Patterns; (2) Rock Paintings. Unpublished report for the Northern Land Council, Darwin.

Lees, B.G. 1992. Geomorphological evidence for late Holocene climatic change in northern Australia. Australian Geographer 23(1):1-10. doi.org/10.1080/00049189208703048

Lewis, D. 1988. The Rock Paintings of Arnhem Land, Australia: Social, Ecological and Material Culture Change in the Post-Glacial Period. British Archaeological Reports International Series 415, Oxford.

Lowe, K.M., L. Wallis, C. Pardoe, B. Marwick, C. Clarkson, T. Manne, M. Smith and R. Fullagar 2014. Ground-penetrating radar and burial practices in western Arnhem Land, Australia. Archaeology in Oceania 49:148-157. doi.org/10.1002/arco.5039

May, S. 2008. Learning art, learning culture: Art, education, and the formation of new artistic identities in Arnhem Land, Australia. In I. Domingo Sanz, S. May and D. Fiore (eds), Archaeologies of Art: Time, Place and Identity, pp. 171-194. Left Coast Press, Walnut Creek.

May, S., P.S.C. Taçon, M. Travers and D. Guse 2010. Painting history: Indigenous observations and depictions of the 'other' in far north Australia. Australian Archaeology 71:57-65. doi.org/10.1080/03 122417.2010.11689384

May, S.K., D. Wesley, J. Goldhahn, M. Litster and B. Manera 2017. Symbols of power: The firearm paintings of Madjedbebe (Malakunanja II). International Journal of Historical Archaeology 21:690-707. doi.org/10.1007/s10761-017-0393-6

Meehan, B., S. Brockwell, J. Allen and R. Jones 1985. The wetland sites. In R. Jones (ed.), Archaeological Research in Kakadu National Park, pp. 103-153. Special Publication 13. Australia National Parks and Wildlife Service, Canberra.

Morley, A.W. 1979. Aboriginal Site Survey of the Jabiluka Project Area. Unpublished Report for Pancontinental Mining Limited, Darwin.

Morley, A.W. and D.W. Lovett 1980. Aboriginal Site Survey of the Jabiluka Project Area. Unpublished report for Pancontinental Mining Limited, Environment Division, Jabiluka Division, Darwin.

Nelson, E. (ed.) 2000. The Beeswax Art of Northern Australia. Simon Fraser University, Burnaby.

Roberts, R.G and R. Jones 1994. Luminescence dating of sediments: New light on human colonization of Australia. Australian Aboriginal Studies 2:2-17.

Roberts, R.G., R. Jones and M.A. Smith 1990a. Thermoluminescence dating of a 50,000-year-old human occupation site in northern Australia. Nature 345:153-156. doi.org/10.1038/345153a0

Roberts, R.G., R. Jones and M.A. Smith 1990b. Early dates at Malakunanja II, a reply to Bowdler. Australian Archaeology 31:94-97.

Roberts, R.G., R. Jones and M.A. Smith 1990c. Stratigraphy and statistics at Malakunanja II: reply to Hiscock. Archaeology in Oceania 25:125-129. doi.org/10.1002/j.1834-4453.1990.tb00243.x 
Roberts, R., H. Yoshida, R. Galbraith, G. Laslett, R. Jones and M. Smith 1998. Single-aliquot and single-grain optical dating confirm thermoluminescence age estimates at Malakunanja II rock shelter in northern Australia. Ancient TL 16:19-24.

Russell-Smith, J., D. Lucas, M. Gapindi, B. Gunbunuka, N. Kapirigi, G. Namingum, K. Lucas, P. Giuliani and G. Chaloupka 1997. Aboriginal resource utilization and fire management practice in western Arnhem Land, monsoonal northern Australia: Notes for prehistory, lessons for the future. Human Ecology 25(2):159-195. doi.org/10.1023/A:1021970021670

Schrire, C. 1982. The Alligator Rivers: Prehistory and Ecology in Western Arnhem Land. Terra Australis 7. The Australian National University, Canberra.

Taçon, P.S.C. 1989. From Rainbow Snakes to 'X-Ray’ Fish: The Nature of the Recent Rock Painting Tradition of Western Arnhem Land, Australia. Unpublished PhD thesis. The Australian National University, Canberra.

Taçon, P.S.C. and S. Brockwell 1995. Arnhem Land prehistory in landscape, stone and paint. Antiquity 69:676-695. doi.org/10.1017/S0003598X00082272

Taçon, P.S.C., E. Nelson, C. Chippindale and G. Chaloupka 2004. The beeswax rock art of the Northern Territory: Direct dating results and a 'book of record'. Rock Art Research 21(2):155-160.

Taçon, P.S.C., S.K. May, S. Fallon, M. Travers, D. Guse and R. Lamilami 2010. A minimum age for early depictions of Macassan praus in the rock art of Arnhem Land, Northern Territory. Australian Archaeology 71:1-10. doi.org/10.1080/03122417.2010.11689379

Taylor, L. 1996. Seeing the Inside: Bark Painting in Western Arnhem Land. Clarendon Press, Oxford.

Wesley, D., T. Jones, S. O'Connor, J. Fenner and W. Dickinson 2014. Earthenware of Malarak, Anuru Bay: A reassessment of potsherds from a Macassan trepang processing site, Arnhem Land, Australia, and implications for Macassan trade and the trepang industry. Australian Archaeology 79:14-25. doi.org/10.1080/03122417.2014.11682015

White, C. 1967a. Plateau and Plain. Prehistoric Investigations in Arnhem Land, Northern Territory. Unpublished PhD thesis, The Australian National University, Canberra.

White, C. 1967b. The prehistory of the Kakadu People. Mankind 6:426-431.

White, C. 1967c. Early stone axes in Arnhem Land. Antiquity 41:149-152. doi.org/10.1017/ S0003598X00112839

White, C. 1971. Man and environment in northwest Arnhem Land. In D.J. Mulvaney and J. Golson (eds), Aboriginal Man and Environment in Australia, pp. 141-57. Australian National University Press, Canberra.

Woodroffe, C.D., J. Chappell and B. Thom 1988. Shell middens in the context of estuarine development, South Alligator River, Northern Territory. Archaeology in Oceania 23:95-103. doi.org/10.1002/j.1834-4453.1988.tb00196.x

Woodroffe, C.D., J. Chappell, B. Thom and E. Wallensky 1989. Depositional model of a macrotidal estuary and floodplain, South Alligator River, northern Australia. Sedimentology 36:737-756. doi.org/10.1111/j.1365-3091.1989.tb01743.x 
This text is taken from The Archaeology of Rock Art in Western Arnhem Land, Australia, edited by Bruno David, Paul Taçon, Jean-Jacques Delannoy and Jean-Michel Geneste, published 2017 by ANU Press, The Australian National University, Canberra, Australia. 